\title{
Implications of Pro-market Land Policies on Customary Land Users in Zambia: A Case of Large-Scale Land Investments in Kaindu Chiefdom, Mumbwa District
}

\author{
Anthony Mushinge ${ }^{1} \&$ Sam Mwando ${ }^{1}$ \\ ${ }^{1}$ Chair of Land Management and Land Tenure, Technical University of Munich, Munich, Germany \\ Correspondence: Anthony Mushinge, Chair of Land Management and Land Tenure, Technical University of Munich, \\ Arcisstrasse 21, D-80333, Munich, Germany.
}

Received: May 3, 2016

Accepted: May 20, 2016

Available online: June 22, 2016

doi:10.11114/ijsss.v4i8.1585

URL: http://dx.doi.org/10.11114/ijsss.v4i8.1585

\begin{abstract}
The purpose of the research is to: 1) establish whether or not the current land policies protect customary tenure in Zambia; 2) investigate the level of awareness of pro-market land policies by customary land users in Zambia; 3) investigate the impact of pro-market land policies on customary land users in view of large scale land acquisition in Zambia; 4) investigate the constraints in administering customary land in view of the large scale land acquisitions in Zambia; and 5) recommend mechanisms to put in place by government that may improve customary tenure security in view of large scale land acquisition in Zambia. Methodologically, qualitative methods (largely in-depth interviews and focus group discussions) were used to conclude that current land law and regulations regarding the large scale allocation of customary land for investment are weak and therefore unable to protect the rights of land users. In trying to achieve the objectives of the country in attracting more land based investments, communities occupying land in customary areas are increasingly being displaced without or with meagre compensation. Displacements in turn lead to socio-economic exclusion, land conflicts, tenure insecurity, and enclosures of common pool resources. We recommend the adoption of a pro-poor land policy which provides a holistic and well balanced approach to governing large scale land investments in customary settings, and establishment of mandatory village land trusts to preside over all land related matters in order to have an all-encompassing representation in decision making regarding allocation of large parcels of land.
\end{abstract}

Keywords: Zambia, customary land, pro-market land policies, large scale land investments

\section{Introduction}

Customary land is an asset of the greatest importance in many parts of Africa. It forms the basis for existence as all forms of production, food, shelter and human sustenance rely on its presence (Chikhwenda, 2002). In this regard, customary land is considered an important resource that serves the needs of humanity for livelihood purposes (Tutu et al., 2016). Despite its importance, users of customary land in Africa have come under profound threat in recent times due to large-scale land investments (LSLIs). A combination of factors on the global stage has over the last decade led to a rapid expansion in large-scale investments by foreign and local investors - currently referred to as land grabbing - on customary land. These factors include policy commitments to biofuels and renewable energy, increased demand for resources by emerging economies, rising and unstable commodity prices, and improved investment prospects given anticipated future demand for water, food, and energy (Anseeuw et al., 2012; Cotula, 2011; De Schutter, 2011; World Bank, 2011). The rationale for LSLIs has come into debate regarding the demerits, especially on the local communities living where large-scale investments are set up (German et al., 2013). Literature shows that LSLIs have denied the majority of indigenous people in Africa the right to land and decent livelihoods, threatened food, water and tenure security and promote conflicts over land (Friis and Reenberg, 2010; Graham et al., 2011; Kachika, 2010; World Bank, 2011).

In Zambia the narrative on LSLIs is not very unique to many other sub-Saharan African countries experiencing this phenomenon. In 1995, the Lands Act was enacted and this Act provides for the conversion of customary land to state land (held under statutory tenure). According to section 8 (1) of the Lands Act of 1995, a holder of land under customary tenure may convert it into leasehold tenure not exceeding ninety nine years on application. This was done with the primary objective of incentivising land based investments in the country. Some of the targeted sectors were 
agriculture, tourism and mining (Oakland Institute, 2011). This is being done to encourage economic growth, employment creation and infrastructure development in rural areas.

In spite of the 1995 Lands Act paving way for investment, very little was done in the way of ensuring that the land rights of local communities who own land on customary basis were legally protected. The land law only recognises the existence of customary land, but lacks the necessary enforcement to safeguard the rights of the customary land users (Crabtree-Condor and Casey, 2012; Nolte, 2013). As a result, there is widespread eviction threats/displacements, elite capture, socio-economic exclusion, intra-community conflicts, community disquiet, sub-divisions and enclosures of common pool resources (Mushinge and Mulenga, 2016). For example, in recent years land based investments (see table 1) in the mining, tourism and agricultural sectors, and also increasingly industrial developments, have led to displacements of communities.

Table 1. Displacements due to large-scale land investments in Zambia

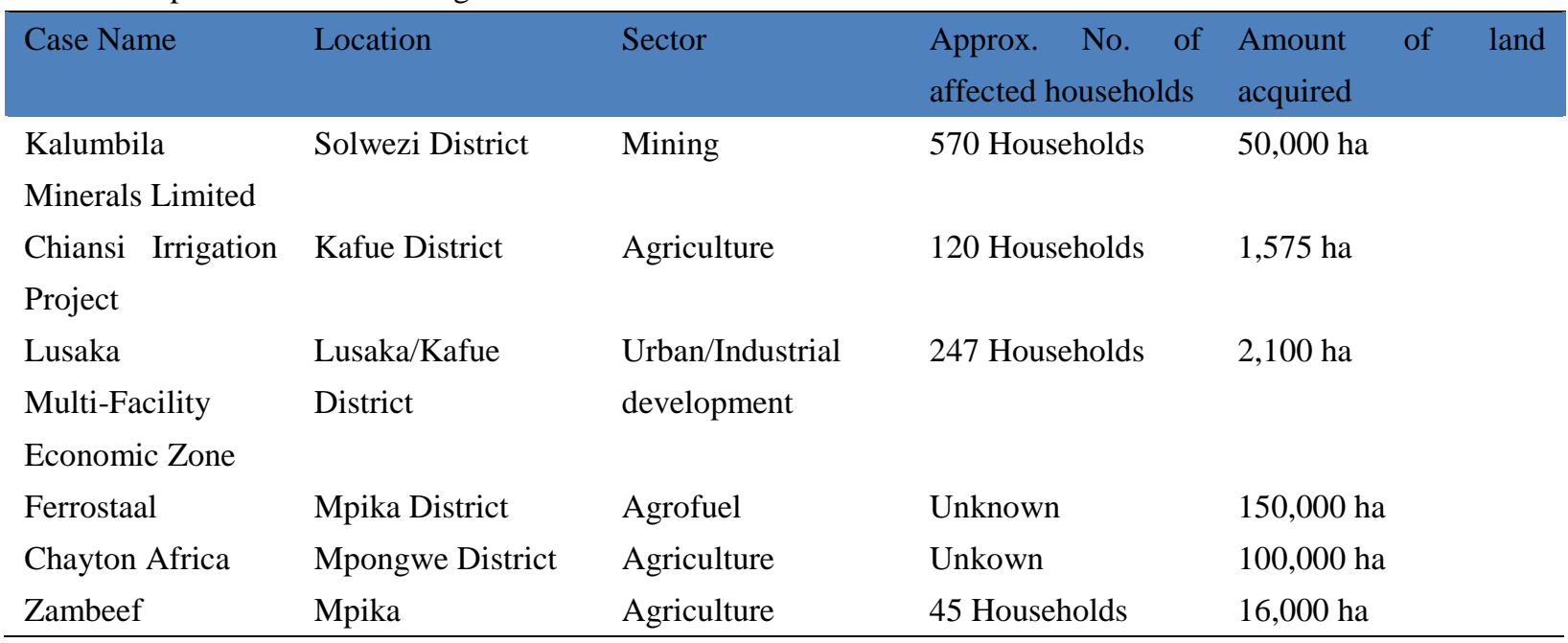

Source: Chu et al. (2015) modified by Authors

Against this background, this paper evaluates the implications of pro-market land policies on customary land users focusing on large scale land investments. In so doing, we attempt to answer key questions, including: 1) how do the current land policies protect customary tenure in Zambia? 2) How much is the level of awareness of pro-market land policies by customary land users in Zambia? 3) What is the impact of pro-market land policies on customary land users in view of large scale land acquisition in Zambia? 4) What are the constraints in administering customary land in view of the large scale land acquisitions in Zambia? And 5) what mechanisms need to be put in place by government that may improve customary tenure security in view of large scale land acquisition in Zambia? The paper draws on international literature, personal experience and research in Zambia to find answers to these questions.

\section{Theoretical Framework}

\subsection{Customary Land Tenure}

Customary tenure implies holding of land based on customs/traditions (Cotula, 2007; Van Asperen and Mulolwa, 2008). This tenure is characterised by communal possession of land rights by a group sharing the same cultural identity (Payne and Durand-Lasserve, 2012). A single person (e.g. traditional leader) usually administers on behalf of the group (ibid). In Africa, customary tenure is often applicable in rural, and in some cases peri-urban areas. In fact, looking at area coverage, customary tenure forms the most important tenure class in most African countries (Van Asperen, 2007), covering not less than $80 \%$ of land (Olawore, 2006). Land under this tenure has no documentary evidence or confirmed tenure, making insecure land in Africa the majority (Deininger, 2003; Olawore, 2006). Nonetheless, literature review shows that some countries (e.g. Uganda, Mozambique, Tanzania, Niger, Namibia, Botswana, Tanzania, and South Africa) have to varying degrees, enacted laws that protect customary land rights and provide for or allow their registration (Cotula et al., 2004). This implies that customary land rights in these countries are granted equivalent legal status and protection to that of statutory tenure.

\subsection{Land Policies and Customary Land}

Land policy is the course of actions defined by the state in order to govern modalities of land acquisition and security of rights to land (Au et al., 2012). It is contained in texts issued by governments, and includes legislation, decrees, rules and regulations as well as administration structures and programmes (EU, 2004). A land policy is essentially an expression of a government's perception of the direction to be taken on major issues related to land (Hands On, n.d.). As 
such, land policy always implies a political decision of setting priorities and following specific aims (ibid). Land policy lies at the heart of economic and social life and environmental issues in all countries (Au et al., 2012). Land policies can be categorised as pro-market and pro-poor. This is something that is explored in more detail in the next subsections.

\subsubsection{Pro-market Land Policies}

These land policies encourage large-scale land investments (LSLIs). Large-scale land investments refers to a situation where large areas of arable land (mostly customary land) change hands through deals often negotiated between host governments and foreign or local investors with little or no participation from the local communities who depend on access to those lands for their livelihoods (De Schutter, 2011). Proponents of large-scale land investments highlight the numerous benefits. These include poverty reduction, increased food supply, job creation, technology transfer and rural infrastructure development (Cotula et al., 2009; Otsuka and Yamano, 2006; von Braun and Kennedy, 1994). Host governments are instrumental in the promotion of these LSLIs. The measures to encourage increased land based investments have been firmly enshrined in national laws and regulations. These instruments have been enacted to expedite the processes of acquiring customary land by would be investors.

On the negative side, literature highlights problems associated with LSLIs. These include widespread alienation of land from local communities without adequate compensation and thus increasing poverty, food insecurity, and the loss of identity, and marginalisation of (family) smallholder producers in favour of large scale investors who receive better protection (AU et al., 2014; Borras JR and Franco, 2012; Bues, 2011; Guillozet and Bliss, 2011; Smaller and Mann, 2009). Underlying factors include: weak land administration systems which fail to protect land rights of communities; poor land records and information systems which do not adequately document land, land rights and claims; weak institutions which do not promote transparency and accountability, and unequal power relations and resourcing of investors and governments or communities during contract negotiation in the context of fiscal and trade regimes that favour globalisation/liberalisation (AU et al., 2014). Reversing this negative scenario require pro-poor land policies. Its advocates contend that these policies are the ideal means of guaranteeing land rights to the poor (UN-Habitat, 2003). The following subsection considers the attributes of the pro-poor land policy.

\subsubsection{Pro-market Land Policies}

Pro-poor land policies effectively secure the land rights of poor people (in this case customary land users). These are guided by international human rights declarations and conventions as well as regional declarations. Key among these are the International Labour Organization's Convention number 169 of 1989 (ILO, 1989), African Charter on Human and Peoples Rights (Organisation of African Unity, 1981), and the United Nations Declaration on the Rights of Indigenous Peoples (the UN Declaration) (United Nations, 2008). Article 14 of the ILO Convention, implores governments to take steps as necessary to identify the lands (customary lands) which the peoples concerned traditionally occupy, and to guarantee effective protection of their rights of ownership and possession (ILO, 1989). Here, measures have to be taken to safeguard the right of the peoples concerned (customary land users) to use lands occupied by them (ibid). In this regard, governments are implored not to remove customary land users from the lands which they occupy. Where customary land users are to be relocated, free and informed consent is required from them and appropriate procedures established by national laws and regulations such as providing adequate compensation are to be followed. Further, Article 17 (3) of the Convention prevents outsiders from taking advantage of customary land users' lack of understanding of the land laws to secure the ownership, possession or use of land belonging to them.

Article 14 of the African Charter on Human and Peoples Rights urge governments to guarantee the right to property (Organisation of African Unity, 1981). Particularly, governments are implored to protect the customary land users' rights to property by putting in place appropriate pieces of legislation. In this regard, by expropriating customary lands in order to promote private investment, states are abrogating human rights of marginalised communities (Mushinge and Mulenga, 2016).

Apart from the International Labour Organization's Convention and African Charter on Human and Peoples Rights, the UN Declaration was developed to further reaffirm the need for governments to protect rights of customary land users (Markay, 2004; United Nations, 2008). Article 26 of the UN Declaration, states that:

Indigenous peoples have the right to the lands, territories and resources which they have traditionally owned, occupied or otherwise used or acquired. Indigenous peoples have the right to own, use, develop and control the lands, territories and resources that they possess by reason of traditional ownership or other traditional occupation or use, as well as those which they have otherwise acquired. States shall give legal recognition and protection to these lands, territories and resources. Such recognition shall be conducted with due respect to the customs, traditions and land tenure systems of the indigenous peoples concerned (United Nations, 2008: 10).

It is evident from the foregoing discussion that interest in the welfare of customary land users, is growing all over the 
world. It is argued that this is, in part, because of the growing awareness from the international community of the existence of a direct link between rural peoples and sustainable socio- economic development (Durning, 1992).

\section{Methodology}

The research was primarily qualitative in nature and adopted a case study approach, where Kaindu Chiefdom in Mumbwa District was studied. Figure 1 is illustrative.

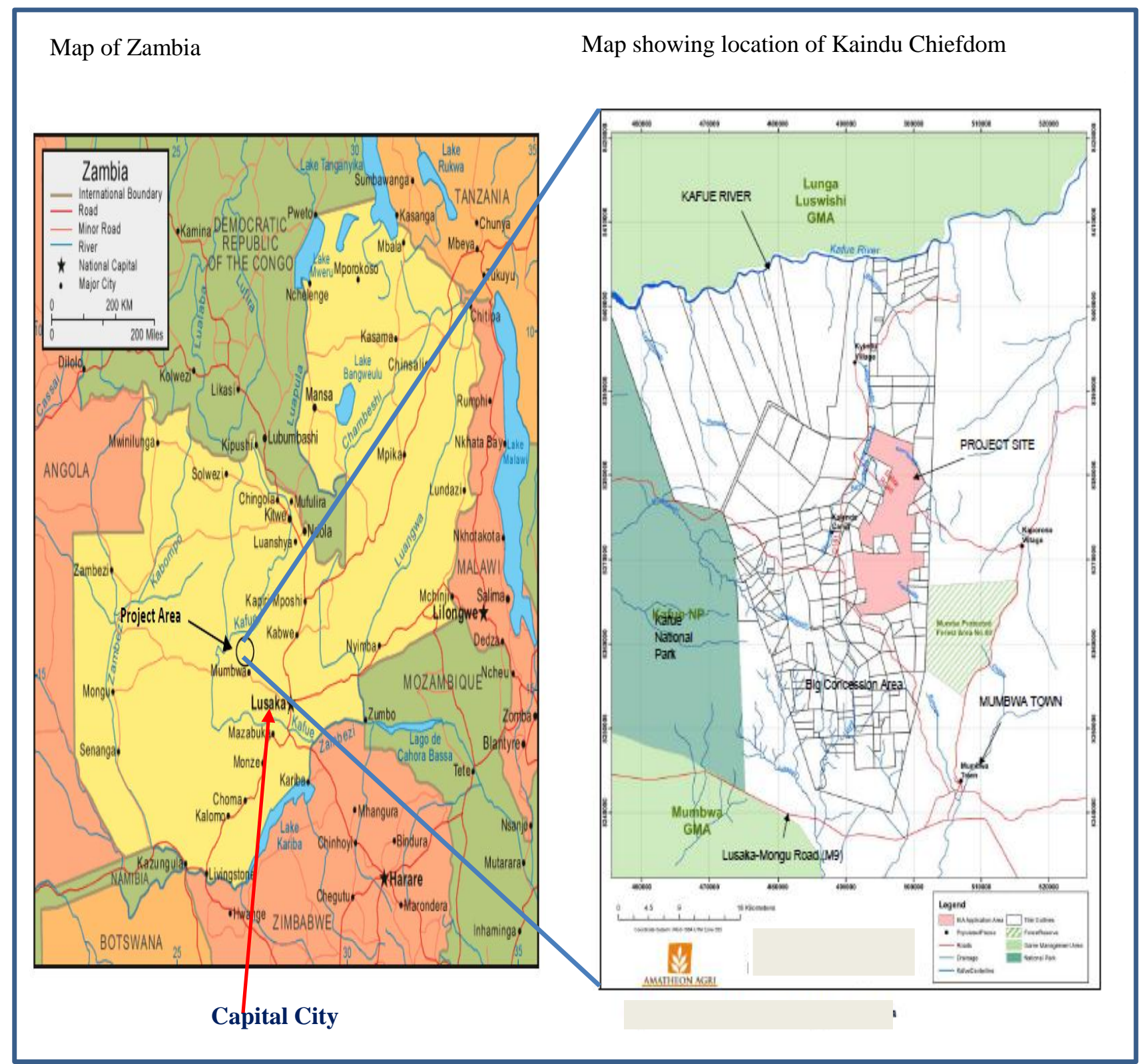

Figure 1. Map showing location of study area (Source: modified from Environment Impact Assessment Report, 2013)

Kaindu Chiefdom, in particular, and Mumbwa District, in general, were chosen as an ideal case that would provide empirical data on large-scale land investments and customary land rights. At national level key informants included legal and lands officers at the Ministry of Lands, legal officer at the Ministry of Chiefs and Traditional Affairs, a representative from Zambia Environmental Management Agency (government institution which inter alia review environmental impact assessment reports), and a representative from Zambia Development Agency (government institution promoting investment in the country). Other key informants at national level included academics from Copperbelt University and University of Zambia (Universities involved in research and teaching in land governance), and a representative from the Zambia Land Alliance (a consortium of non-governmental organisations with a stake in land matters).

At local level respondents included traditional rulers, a representative from the Department of Agriculture in Mumbwa 
District, local authority representative at Mumbwa Municipal Council; and a representative from the Zambia Land Alliance District Office. The main method of data collection used with the stakeholders at both national and local level was in-depth face-to-face interviews. Secondary data were also gathered through an analysis of international literature as well as judgments on land-related cases obtained from within Africa. Fieldwork was conducted between August and November, 2015.

Further, focus group discussions were conducted with indigenous local communities as customary land users in the Kaindu chiefdom in order to determine the consistency of empirical data from other key stakeholders, thereby also enhancing data validation and reliability. This method of data collection was considered most appropriate since the indigenous landholders were more open to discuss in groups than as individuals. This mode of communication was also found to be the norm in most rural areas of Zambia. Furthermore, focus group discussions were found to be more vibrant and facilitated interjection from other members of the group.

In terms of sampling, the study adopted non-probability sampling because the population size was not entirely known, making it difficult to determine individual probability. Under the non-probability sampling techniques, purposive sampling and convenience sampling were chosen. The former was used to select stakeholders that were known beforehand that they had a role to play in land matters (e.g. chiefs, lands officers, and relevant land administration agencies), while the latter was used to select rural communities.

\section{Results and Discussion}

\subsection{Protection and Recognition of Customary Land Rights}

The study participants held the perception that while the Zambian land law recognises the legitimacy of customary land rights, it however is very weak and porous on protecting the rights of people owning land in customary areas. All the 10 respondents, from academia, non-governmental organisation to government departments were of the view that there are currently no robust mechanisms to ensure that the rights of the land users in customary areas are protected. The study showed that there are a number of reasons why land rights of people holding land under customary tenure is threatened namely:

- 1995 Lands Act has made it possible for anyone/entity (local or foreign) to acquire land, simply by negotiating with a chief and with local government endorsement;

- $\quad$ The economic policy of the government has created incentives that attracts domestic as well as foreign investors to acquire land for commercial farming, ignoring the land rights of the local population; and

- The commodization of customary land has shifted the responsibility of the traditional leaders tasked with administering land on behalf of their people (subjects) to pecuniary ends.

The study further revealed other reasons that threaten the integrity of customary land rights. These included the proximity of certain rural areas to big or emerging towns or cities making them a target of people and big companies looking to buy cheap and sparsely populated lands, and the availability of fertile soils, water resources, and cheap labour. Investors acquire land that is empty or inhabited. Where land is inhabited, customary land users are displaced without or with meagre compensation. One of the respondents interviewed stated that:

While it is important that the government recognises customary land rights by law, immediate measures must be put in place to ensure the protection of land rights especially for the rural poor, who cannot afford to hire lawyers to represent them in case of arbitrary evictions without just compensation, and also because now customary land has suddenly become gold mines for the local elites and foreign corporations looking to invest as can be seen almost every month in the media (Government official respondent \# 2).

The research findings from the study area also indicate that the land users do not feel that their land is protected by law. The study showed that this was evident in the manner in which investors and local government officials conduct themselves. One of the study participants recounted his frustration during the focus group discussion:

The only way that we can have some confidence in this current system of owning land is having official documentation from government showing that we own the land here like people in urban areas. Otherwise we shall continue witnessing land surveyors coming in the villages at night to put beacons, and in the morning investors coming with Zambia police to chase us off the land we have occupied for many years (Local land user participant \# 3).

This finding shows how unresponsive the current land policies are to the needs of the local communities in the study area. It also shows that while the intention of the policies may have been to attract more land investments in customary areas, its effects in practice seem to be negative, at least for the people who solely depend on the land for their daily sustenance. This situation is creating land pressures for local communities, who not only need land to farm on, but the 
common resources such as water and forests. Therefore, there is a lack of balance between ensuring that the benefits of agricultural investments benefit the country in tax revenue and overall productivity and safeguard the rights of the local poor populations. This situation therefore, threatens the tenure security of the customary land users.

\subsection{Level of Awareness of Pro-market Land Policies}

The study revealed that all respondents (customary land users) from the study area did not know anything about the land laws guiding customary land administration. For instance, local land users are not aware of the implication of the 1995 Lands Act and how it directly affects their land rights and also access to common pool resources such as grazing land, water and forests. The study further revealed that customary land users' lack of awareness about the land laws guiding customary land administration has prompted some investors, traditional leaders and government officials to remove people from their land without just compensation. This lack of awareness is increasingly creating land conflicts between investing companies and local communities who feel betrayed by the system. Local land users, still hold the misguided notion that just because they have lived on the land for many years, they must continue to do so despite the land being converted to state land by new owners.

\subsection{Impact of Pro-market Land Policies on Customary Land Users}

All key respondents indicated that while the current land laws provide for ensuring that before land is allocated in customary area, affected people should be adequately compensated or relocated, and that the people should be consulted before land is sold to any buyer, this is not happening in practice. Thus, large scale land acquisitions have led to widespread displacements, socio-economic exclusion, land conflicts, tenure insecurity, and enclosures of common pool resources. For instance, once investors have acquired customary land by converting it to statutory land (titled land), this land ceases to be accessible by the larger community. Any attempt to use resources from the 'now titled land' is trespassing and punishable by law. This creates conflicts between the local land users and the new comers, because the land users still believe that they must have access to the land. The actions of the local land users may suggest that the local communities do not understand the dictates of the law regarding private land ownership. One of the participants commented:

When this company came to this area, we were very happy that development had come to our village. However, over the years what was agreed, such as allowing access to forest lands within the chiefdom has changed now. It is now illegal for us to pick firewood in those areas (local land users' participant \# 18).

From the FGDs and interviews conducted, it is clear that the lack of clear guidelines to protect the interests of the local communities in the face of large scale agricultural investments creates numerous land problems.

\subsection{Constraints in Administering Customary Land}

The majority of respondents cited limitations by traditional authorities to adequately administer customary land in the study area. Professionals at government departments responsible for administration of customary land acknowledged these limitations as an inevitable cost of pro-market policies on customary settings. One of the respondents from the ministry of chiefs and traditional affairs commented:

It is a one-way street now, any land targeted by investors risks being converted to statutory land.....and unfortunately our traditional leaders are ill-equipped to manage this process. Clearly at the rate we are going, it is undeniable that traditional leaders do not have the capacity to administer land in their respective chiefdoms. And a lot of families now risk losing land (MCTA participant \# 18).

Interviews revealed that despite the land reforms of 1995, which opened up customary land to investments, very little has been done to equip the traditional leaders with the necessary skills and competencies to manage this important tenure type in Zambia. The study respondents stated that this lack of technical oversight at that stage of land administration is the cause of the numerous negative consequences. Commenting on the state of land administration in customary areas, one of the participants noted:

The entire land administration process in the village depends on the integrity or lack thereof of one person, the traditional leader, and that is a recipe for disaster (Land expert participant \#48).

The majority of key respondents revealed that traditional leaders did not consider matters of land use, environmental aspects, or how the developments will impact on the local communities. These respondents considered this knowledge necessary because traditional authorities were the first point of contact for people or companies seeking land. They stated that once the traditional leaders allocate land to investors, it is very rare to reverse that decision at any later stage. Therefore, on the discretion of the chief, and without any understanding of the operations of the incoming investors, large tracts of land are sold at the expense of local land users. This was thought to be a problem because once an investor converts the land into statutory land, that decision cannot be reversed, hence local land users lose out.

Study participants in the study area bemoaned the lack of knowledge by their traditional leaders to ascertain the exact 
extent of their land. They noted that this has become a concern to the local people, because investors bring government land surveyors to demarcate the land, and it is not easy to know if they are getting more land than initially allocated to them. Participants also reported on the difficulties of traditional leaders in accurately allocating land to investors, land which in some cases involves important communal land. One of the local land users challenged the senior headman within the study area:

Please ask the senior headman here if he knows the boundaries of his village. People are coming in this village and because they come with land surveyors, they claim any amount of land. This is because we do not have the capacity of knowing exactly where our land starts and ends, that's a big problem we have now (FGDs participant \#21).

Based on the foregoing, the capacity of traditional leaders in managing customary land is not matched with the complexity of dealing with large-scale land acquisitions in the study area. Negotiating land sales with expert agriculturalists, soil experts, lawyers and trained negotiators is a contradiction in this entire process. Without adequately capacitating the traditional leaders with the necessary knowledge and competencies of land administration, the problems inherent with such land acquisitions will persist with negative consequences for the poor customary land users. Evidence from the FGDs and interviews indicates that the land administration system at village level is not equipped to handle the many factors that are associated with large-scale land investments. The traditional leaders neither have the resources nor the technical know-how to vet the investments coming into their areas. While there may be some immediate monetary benefits for traditional leaders, their actions have far reaching consequences on the tenure security of their subjects in the long run. This is especially critical for local peoples' access to communal resources such as water, grazing land and forests for fuel which become restricted once land changes hand.

While the narrative on large-scale investments has pointed to the fact that investors are acting irresponsibly by acquiring huge tracts of land, evidence in this study shows that the weak land administration system at the village level makes it easy for people/companies seeking land to acquire it. These actors operate within the confines of the weak land administration system that is fraught by untrained people administering land, on which the majority rural people depend on.

Further, interviews revealed the issue of corruption in the entire customary land acquisition process. Respondents indicated that there are various stages at which bribes are given or solicited by either those acquiring the land or those allocating land. Respondents articulated how susceptible the process is to corruption especially at the village level. They observed that the lack of a written code predisposes customary tenure to abuse through illicit dealings. This was also attributed to the undemocratic traditional structures where the final decisions are made by the chief alone. Hence, the integrity of the process or lack thereof, at least at the village level depends on the chiefs right or erroneous decisions that he/she makes. According to the respondents, traditional leaders have received all types of gifts or offers, from cash, vehicles, houses in the capital city, and promises of building schools, clinics, to holiday packages in countries of the investor and appointment on the board of the companies. According to tradition, the presentation of gifts is acceptable; however this practice has unfortunately been used for other ulterior motives by both the giver and the receiver. The traditional leaders manage the customary land on behalf of their subject, and any decisions made are supposed to be in the interest of the entire village. The respondents stated that once the chief has given the letter of consent, the procedures at the district council to endorse the land allocation are equally fraught with corruption. This attributed to the fact that despite their lack of resources to ascertain the situation on the ground, they still issue letters of recommendation to the Ministry of Lands endorsing the acquisitions. While their role involves among other things to ensure that the land is not inhabited by local communities, the presence of people (on the land being sought) is ignored or underplayed due to corrupt practices. A respondent from the Ministry of Lands commented:

Our traditional leaders have in the recent years become business people, they sometimes invite "investors" to their chiefdoms, allocate them with very prime land, with rivers passing through them. In return they accept personal gifts. And there is no accountability in the process. Unfortunately up to the stage that the district council recommends that the land be converted to state land, we are not involved in the process (Expert interview participant \#8).

Based on the foregoing, it is evident that corruption in the process of land acquisition in customary areas is inundated with corrupt practices at different stages. The results of the study agree with previous research on the prevalence of corruption in large- scale land investments in Zambia (see Mbinji, 2012; McShane and Nilsson, 2010; Republic of Zambia, 2012; Tygesen, 2014). While the degree or magnitude of the level of corruption is not easily quantifiable, its effects impacts negatively on the affected customary land users. This is because laws and regulations that are meant to protect the rights of the local communities are flouted with impunity by the major players in the process. The unwritten nature of customary land law also worsens this situation because there is a lack of an audit trial to monitor the rigor of the process. Furthermore, the presence of corruption at this level is not entirely surprising as this scourge is common 
place in the Zambian public sector. The occurrence and extent of corruption depends on many factors: economic and social instability, undemocratic leadership structures, the lack of appropriate legislation and regulations, lack of control, lack of transparency, lack of professional ethics, and the greediness of economic and political elites.

\section{Conclusion and Recommendation(s)}

What seems to emerge from this research is that the current land laws and regulations guiding the large scale allocation of customary land for investment are weak and therefore unable to protect the rights of land users. In trying to achieve the objectives of the country in attracting more land based investments, communities occupying land in customary areas are increasingly being displaced without or with meagre compensation. Furthermore, the research reveals that local land users are not aware of the implication of the 1995 Lands Act and how it directly affects their land rights and also access to common pool resources such as grazing land, water and forests. This is due lack of clear education or information dissemination by relevant authorities such as traditional leaders and government on large scale land acquisitions. As a result, these large scale land acquisitions have led to widespread displacements, socio-economic exclusion, land conflicts, tenure insecurity, and enclosures of common pool resources. In addition, research reveals that there are constraints in administering customary land and these include lack of necessary skills and competencies by traditional leaders to manage customary land, and corruption in the entire customary land acquisition process. These findings therefore question the extent to which (if at all) the international law on the rights of indigenous people with respect to property rights/land (like the ILO Convention 169, African Charter and UN Declaration) are respected/domesticated in Zambia (Mushinge and Mulenga, 2016).

In view of our findings, we recommend the following: 1) adoption of a pro-poor land policy which provides a holistic and well balanced approach to governing LSLIs in customary settings. This approach can incorporate principles of equity, transparency and deliberate engagement of local land users in decision making processes. This can be achieved by amending the existing legal and regulatory framework and ensuring enforcement by applying evaluation and monitoring techniques periodically. In addition to this, involving the civil society to offer the necessary checks and balances to the process of land allocations in rural settings is needed; and 2) establishment of mandatory village land trusts to preside over all land related matters in order to have an all-encompassing representation in decision making regarding allocation of large parcels of land. This will mean that decisions that involve the allocation of land will receive consensus of the entire village community. In order for this to be achieved, both men and women should be represented equally on this committee.

\section{Acknowledgements}

The authors acknowledge the assistance provided by: Legal and Lands Officers at the Ministry of Lands (Lusaka); Local Authority Representatives at Mumbwa District Council; Zambia Land Alliance; and customary landholders in Kaindu chiefdom in Mumbwa District.

\section{References}

Anseeuw, W., Alden Wily, L., Cotula, L., \& Taylor, M. (2012). Land Rights and the Rush for Land: Findings from the Global Commercial Pressures on Land research project. Rome: International Land Coalition.

AU, ECA, \& AfDB (2012). Land Policy in Africa: Central Africa Regional Assessment. Addis Ababa: AUC-ECA-AfDB Consortium.

AU, ECA, \& AfDB (2014). Guiding Principles on Large Scale Land Based Investments in Africa. Addis Ababa: Economic Commission for Africa.

Borras, J. R., S. M., \& Franco, J. C. (2012). Global land grabbing and trajectories of agrarian change: A preliminary analysis. Journal of Agrarian Change, 12(1), 34-59. http://dx.doi.org/10.1111/j.1471-0366.2011.00339.x

Bues, A. (2011). Agricultural foreign direct investment and water rights: An institutional analysis from global land grabbing. International Conference on Global Land Grabbing, 6-8 April 2011. University of Sussex.

Chikhwenda, E. J. W. (2002). Transactive land tenure system in the face of globalisation in Malawi. Paper presented at the 9th IASCP (International Association for the Study of Common Property) Biennial Conference: The commons in the age of globalisation 17 - 21 June 2002, Victoria, Zimbabwe.

Chu, J., Young, K., \& Phiri, D. (2015). Large-Scale Land Acquisitions, Displacements and Resettlement in Zambia. Policy Brief 41. Institute for Poverty, Land and Agrarian Studies (PLAAS). University of Western Cape.

Cotula, L., Toulmin, C., \& Hesse, C. (2004). Land Tenure and Administration in Africa: Lessons of Experience and Emerging Issues. London: International Institute for Environment and Development. 
Cotula, L. (2007). Changes in Customary and Tenure Systems in Africa. London: International Institute for Environment and Development.

Cotula, L., Vermeulen, S., Leonard, R. \& Keeley, J. (2009). Land Grab or Development Opportunity? Agricultural Investment and International Land Deals in Africa. London/Rome: IIED/FAO/IFAD.

Cotula, L. (2011). The Outlook on Farmland Acquisitions. Rome: International Land Coalition.

Crabtree-Condor, I, \& Casey, L. (2012). Lay of the Land: Improving Land Governance to Stop Land Grabs. Johannesburg: ActionAid International Secretariat.

Deininger, K. (2003). Land Policies for Growth and Poverty Reduction. A World Bank Policy Research Report. Washington DC: World Bank.

De Schutter, O. (2011). The green rush: The global race for farmland and the rights of land users. Harvard International Law Journal, 52(2), 503-559.

Durning, A. T. (1992). Guardians of the land: Indigenous peoples and the health of the earth. Washington, DC: Worldwatch Institute.

EU (2004). Guidelines for Support to Land Policy Design and Land Policy Reform Processes in Developing Countries. EU Land Policy Guidelines.

Friis, C., \& Reenberg, A. (2010). Land Grab in Africa: Emerging Land System Drivers in a Teleconnected World. GLP Report No. 1. Copenhagen: GLP-IPO.

German, L., Schoneveld, G, \& Mwangi, E. (2013). Contemporary processes of large-scale land acquisition in sub-Saharan Africa: legal deficiency or elite capture of the rule of law? World Development, 48, 1-18. http://dx.doi.org/10.1016/j.worlddev.2013.03.006

Graham, A., Aubry, S., Künnemann, R., \& Monsalve Suárez, S. (2011). The role of the EU in land grabbing in Africa CSO monitoring 2009-2010 Advancing African Agriculture (AAA): ihe impact of Europe's policies and practices on African Agriculture and Food Security. Paper presented at the International Conference on Global Land Grabbing. University of Sussex. 6-8 April 2011.

Guillozet, K., \& Bliss, J. C. (2011). Household livelihoods and increasing foreign investment forests global land grabbing. International Conference on Global Land Grabbing, 6-8 April 2011. University of Sussex.

Hands On (n.d.). What is land policy all about? Retrieved April 5, 2016, fromhttp://www.fian.de/fileadmin/user_upload/dokumente/publikationen/HOTL_Land_Policy_Note.pdf.

ILO (International Labour Organisation) (1989). Convention Concerning Indigenous and Tribal Peoples in Independent Countries, No. 169. ILO, Geneva.

Kachika, T. (2010). Land grabbing in Africa: a review of the impacts and the possible policy responses. Retrieved August 12, 2015, from http://www.oxfamblogs.org/eastafrica/wp-content/uploads/2010/11/Land-Grabbing-in-Africa.-Final.pdf.

MacKay, F. (2004). Indigenous peoples ${ }^{e e}$ rights to lands, territories and resources: Selected international and domestic legal considerations". Land Reform: Land Settlement and Cooperatives 2004/1: pp. 80 - 95.

Mbinji, J. (2012). Land justice, land reform and access: proposals for land justice for poor families with particular emphasis on Zambia. Retrieved October 20, 2015, from http://www2.weed-online.org/uploads/land_justice_land_reform_and_access_2012.pdf.

McShane, K., \& Nilsson, J. (2010). Determinants of Corruption: A Study of Zambian Ministries. Bachelor's Thesis. Lund University: Lund.

Mushinge, A, \& Mulenga, S. (2016). Legal pluralism and tenure security: exploring the relationship between statutory and customary land tenure in Zambia. International Journal of Social Science Studies, 4(3), 7-17. http://dx.doi.org/10.11114/ijsss.v4i3.1331

Nolte, K. (2013). Large-Scale Agricultural Investments under Poor Land Governance Systems: Actors and Institutions in the Case of Zambia. Hamburg: GIGA German Institute of Global and Area Studies.

Nyametso, J. K. (2010). Improvement of Squatter Settlements: The Link between Tenure Security, Access to Housing, and Improved Living and Environmental Conditions. PhD Thesis. University of Otago: Dunedin.

Oakland Institute (2011). Understanding Land Investment Deals in Africa: Country Report-Zambia. Oakland: The Oakland Institute. 
Olawore, K. A. (2006). Land titling and registration in Nigeria: procedures, costs and implications in Lagos state. CASLE Conference paper.

Organisation of African Unity (1981). African Charter on Human and Peoples Rights. Addis Ababa: Organisation of African Unity

Otsuka, K., \& Yamano, T. (2006). The role of rural labor markets in poverty reduction: Evidence from Asia and East Africa. Retrieved April 5, 2016, from

https://openknowledge.worldbank.org/bitstream/handle/10986/9238/WDR2008_0025.pdf?sequence=1\&isAllowed=y.

Payne, G., \& Durand-Lasserve, A. (2012). Holding on: security of tenure - types, policies, practices and challenges. Research paper prepared for an expert group meeting on security of tenure convened by the Special Rapporteur on 22-23 October 2012.

Republic of Zambia (1995). Lands Act. Lusaka: Government Printers.

UN-Habitat (2003). Handbook on Best Practices, Security of Tenure and Access to Land, Implementation of the Habitat Agenda. Nairobi: UN-Habitat.

United Nations (2008). Declaration on the rights of indigenous peoples. Resolution 61/295 of 13 September 2007, United Nations, Geneva.

Smaller, C., \& Mann, H. (2009). A Thirst for Distant Lands: Foreign Investment in Agricultural Land and Water. Manitoba: Winnipeg.

Tutu , D, O., Asante L, A., Appiah, M. N., Bendzko, T., \& Chigbu, U. E. (2016). Towards a pro-poor customary land rights security in rural Ghana: Land tenure inventory using mobile application by local youth. Paper prepared for presentation at the "2016 World Bank Conference on Land and Poverty". The World Bank - Washington DC, 14-18 March, 2016

Tygesen, P. (2014). No clear grounds: the impact of land privatisation on smallhold farmers' food security in Zambia. Retrieved August 26, 2015, from http://www.mokoro.co.uk/files/13/file/NoClearGrounds.pdf.

World Bank (2011). Rising Global Interest in Farmland: Can it Yield Sustainable and Equitable Benefits? Washington, DC: World Bank.

Van Asperen, P., \& Mulolwa, A. (2006). Improvement of customary tenure security as pro-poor tool for land development: A Zambia case study. Paper presented at the 5th FIG Regional Conference, Accra, Ghana, 8-11 March, 2006.

Van Asperen, P. C. M. (2007). Effects of multiple land tenure regimes on tenure security: African cases. European Conference on African Studies. University of Technology: Delft.

Von Braun, J., \& Kennedy, E. (1994). Agricultural Commercialization, Economic Development, and Nutrition. Baltimore, Maryland: John Hopkins University Press.

\section{(cc) $\mathrm{Br}$}

This work is licensed under a Creative Commons Attribution 3.0 License. 